\title{
Individual determinants of entrepreneurship in Visegrád countries: Reflection on GEM data from the Czech Republic, Hungary, Poland, and Slovakia
}

\author{
Ondřej Dvouletý, Marko Orel
}

\begin{tabular}{|c|c|}
\hline & A B S T R A C T \\
\hline $\begin{array}{l}\text { Objective: Th } \\
\text { ment and em } \\
\text { Central Europ }\end{array}$ & $\begin{array}{l}\text { article explores the individual determinants driving solo self-employ- } \\
\text { oyer entrepreneurship in four post-communist economies located in } \\
\text { (the Czech Republic, Hungary, Poland, and Slovakia). }\end{array}$ \\
\hline $\begin{array}{l}\text { Research Des } \\
\text { survey, a par } \\
\text { gistic regressi } \\
\text { self-employec } \\
\text { ing traditiona } \\
\text { trepreneurial }\end{array}$ & $\begin{array}{l}\text { \& Methods: The article exploits data from the } 2013 \text { Adult Population } \\
\text { the Global Entrepreneurship Monitor (GEM). Using multivariate lo- } \\
\text { models, we explore the differences between wage-employed, solo } \\
\text { nd employer entrepreneurs (self-employed with employees), concern- } \\
\text { aterminants of entrepreneurship, such as gender, age, education, en- } \\
\text { fidence, and the number of people living in a household. }\end{array}$ \\
\hline $\begin{array}{l}\text { Findings: The } \\
\text { ment - there } \\
\text { likelihood of } \\
\text { differed acro }\end{array}$ & $\begin{array}{l}\text { tained findings show that - regardless of the type of self-employ- } \\
\text { a strong and positive impact of entrepreneurial confidence on the } \\
\text { ng an established entrepreneur. The impact of remaining variables } \\
\text { he type of entrepreneurship. }\end{array}$ \\
\hline $\begin{array}{l}\text { Implications } \\
\text { viduals with a } \\
\text { separately. }\end{array}$ & $\begin{array}{l}\text { ecommendations: This research highlights that self-employed indi- } \\
\text { without employees should be treated in research and policymaking }\end{array}$ \\
\hline $\begin{array}{l}\text { Contribution } \\
\text { body of litera } \\
\text { dividuals and }\end{array}$ & $\begin{array}{l}\text { Ialue Added: The presented research contributes to the growing } \\
\text { e aiming to understand differences between solo self-employed in- } \\
\text { aployer entrepreneurs. }\end{array}$ \\
\hline Article type: & research article \\
\hline Keywords: & $\begin{array}{l}\text { individual determinants of entrepreneurship; self-employment; job } \\
\text { creators; solo self-employed individuals; Global Entrepreneurship } \\
\text { Monitor; Czech Republic; Hungary; Slovakia; Poland }\end{array}$ \\
\hline JEL codes: & $\mathrm{L} 26, \mathrm{~L} 53, \mathrm{P} 42$ \\
\hline Received: 1 & Accepted: 19 August 2020 \\
\hline
\end{tabular}

Suggested citation:

Dvouletý, O. \& Orel, M. (2020). Individual Determinants of Entrepreneurship in Visegrád Countries: Reflection on GEM Data from the Czech Republic, Hungary, Poland and Slovakia. Entrepreneurial Business and Economics Review, 8(4), 123-137. https://doi.org/10.15678/EBER.2020.080407 


\section{INTRODUCTION}

The formation of the Socialist Bloc after the end of the Second World War significantly contributed to the mitigation of private ownership and entrepreneurship and resulted in institutional orientation towards the centrally planned economy among its satellite states (Sachs \& Woo, 1994; Fischer et al., 1996; Švejnar, 2002). After the break-up of the socialist regime in the 1980 s and 1990s, the countries regained their political sovereignty, and they started heading towards an institutional transition from the centrally planned economy to the marketoriented economy (Shama, 1993; Money \& Colton, 2000). Decades of Soviet socialist regime and orientation towards central planning have changed the behaviour of people living in the countries and economic agents to the extent that some scholars introduced the term "homo sovieticus' for the population living under the reign of the former regime (Shiller et al., 1992; Morawska, 1999). The process of economic transition and accompanying reforms was led by experts from abroad who helped to re-establish private ownership that was crucial for the future development of entrepreneurship in post-communist economies (Morwaska, 1999; Dana \& Dana, 2003; Ovaska \& Sobel, 2005; Wallace \& Latcheva, 2006; Cieślik \& van Stel, 2014; Dana \& Ramadani, 2015; Sauka \& Chepurenko, 2017; Kirby \& Watson, 2017).

Based on their former historical cooperation, four of these post-communist economies located in Central Europe (the Czech Republic, Hungary, Poland, and Slovakia) have established an international organisation called the Visegrád Group on 15th February 1991 (also the Visegrád Four or V4), which aims to strengthen their mutual collaboration at the cultural, political, and economic level. Among other goals, the V4 sought to join the European Union, which they achieved on 1st May 2004. (Polok et al., 2016, Visegrád Group, 2019). The V4 member states are the object of this empirically-oriented study as examples of countries that experienced the process of economic transition.

According to the data from the Labour Force Survey (LFS), the overall level of entrepreneurial activity in the $\mathrm{V} 4$ region was on average $13.7 \%$, specifically in individual countries: $15.2 \%$ in the Czech Republic, $10.3 \%$ in Hungary, $16.6 \%$ in Poland and $12.8 \%$ in Slovakia (expressed as a percentage share of 15-64 population) during 2005-2017 (c.f. Dvouletý, 2019, p. 4). The entrepreneurship in the region is considered to be an engine of economic growth (Krasniqi \& Desai, 2016; Dvouletý, 2017a; 2017b; Zygmunt, 2018; Šebestová \& Sroka, 2020); noteworthy, the previous entrepreneurship research in the region was also driven by the willingness of the countries to participate in the Global Entrepreneurship Monitor (GEM). Hungary and Poland joined the GEM initiative as the first countries from the V4 Group in 2003 (Global Entrepreneurship Monitor, 2013). Since then, national GEM teams and other scholars enriched academia about the specifics of entrepreneurship in post-communist economies.

While looking at the previously published studies, the empirical research in the Visegrad region studied many specific aspects of entrepreneurial behaviour. However, we were unable to find a comparable study on the traditional individual determinants of entrepreneurial behaviour described in the literature (e.g. Parker, 2004; Simoes et al., 2016; Muñoz-Bullón et al., 2015; van der Zwan et al., 2016; Mahto \& McDowell, 2018; Laguía et al., 2019; Boudreaux et al., 2019). Following Davidsson's (2015) and Delmar's (2015) call for replication of empirical research in entrepreneurship studies with a focus on regional context, we conduct a comparative study on understanding the differences between wage-employed, solo self- 
employed individuals, and employer entrepreneurs in Visegrad countries. As such, the empirical GEM data analysis was not been conducted in the V4 region, so the presented study marks a high contributing factor to the regional body of knowledge. The article also delivers findings to the current debate on the distinction between self-employed individuals with and without employees (see e.g. Cowling et al., 2004; Petrescu, 2016; Coad et al., 2017; Fairlie \& Miranda, 2017; Dvouletý, 2018; Grace, 2018; Dvouletý et al., 2019; Cieślik \& Dvouletý, 2019) from the perspective of four post-communist economies.

The rest of the article proceeds as follows. We begin by briefly reviewing the existing literature on the determinants of entrepreneurship. The following section introduces the GEM dataset and variables selected for the multivariate logistic regression analysis aiming to capture individual drivers of self-employment with and without employees, which is described in the next section. Then, we summarise the obtained empirical results, and the final part of the paper concludes and provides directions for future research.

\section{LITERATURE REVIEW}

Although individual determinants of self-employment have been studied in the literature extensively (e.g. Rees \& Shah, 1986; Van Praag \& Ophem, 1995; Gerber, 2001; Douglas \& Shepherd, 2002; Parker, 2004; Ekelund et al., 2005; Block \& Sandner, 2009), the current stream of the literature acknowledges (e.g. Simoes et al., 2016; Bögenhold, 2019; Bögenhold et al., 2019; Burke et al., 2019; Van Stel \& Van der Zwan, 2019), that there are different types of self-employed individuals in the economy, which should be differently treated empirically. The most fundamental distinction (i.e. segmentation criteria) we may use is whether self-employed individuals have employees or they remain solo and create work only for themselves (e.g. Cowling et al., 2004; Petrescu, 2016; Coad et al., 2017; Fairlie \& Miranda, 2017; Dvouletý, 2018; Grace, 2018; Dvouletý et al., 2019).

When it comes to evidence from the Visegrád region, individual characteristics and drivers of nascent, youth, and established entrepreneurship were explored, for example, by Lukeš et al. (2013), and Lukeš and Zouhar (2013; 2016) in the Czech Republic; by Szerb and Imreh (2007) and Márkus and Szerb (2013) in Hungary; by Jakubczak and Rakowska (2014), Wach and Wojciechowski (2016), and Głodowska et al. (2019) in Poland; and by Holienka (2014), and Pilkova and Kovacicova (2015) in Slovakia. There also are comparative studies focused on entrepreneurial behaviour in Visegrád countries. Holienka et al. (2016) study youth entrepreneurship and, later (2017), student entrepreneurship. Pilková et al. (2016) analyse the specifics of senior entrepreneurship in Visegrád countries. Barcik et al. (2017) explore the potential of academic entrepreneurship in the V4 region, while Nowiński et al. (2019) examine the entrepreneurial intentions of university students. Finally, Dvouletý et al. (2019) explore the earnings of V4 entrepreneurs. Nevertheless, according to our best knowledge, there is no study that dives deeper into the differences between solo entrepreneurs and employer entrepreneurs.

Therefore, we this article separately studies determinants of self-employed individuals with employees (job creators) and self-employed individuals without employees (solo self-employed) as this topic was not explored in the Visegrád region yet. Since the previously obtained empirical evidence on this topic is rather insufficient and inconclusive, our study can be treated rather as an exploratory one. 


\section{MATERIAL AND METHODS}

\section{Data and Sample}

The article exploits data from the Adult Population Survey (APS) which is a part of the annual Global Entrepreneurship Monitor (2019). The APS explores the characteristics, motivations, and ambitions of individuals starting a business, and their attitudes towards entrepreneurship (Global Entrepreneurship Monitor, 2019). The V4 member states were also historically conducting the APS. Hungary and Poland joined the GEM initiative as the first countries from the V4 Group in 2003. The Czech Republic and Slovakia conducted their first GEM studies in 2006. Most active today is Hungary, which conducted GEM continuously from 2001 to 2016, except for 2003. Poland did GEM in 2001, 2002, 2004, and then continuously from 2011 to 2018. Slovakia is active within GEM continually from 2011 to 2018, and the Czech Republic conducted GEM study only in 2006, 2011, and 2013 (Global Entrepreneurship Monitor, 2019).

For the purpose of our empirical analysis, we need to select only samples coming from the same years; otherwise, the country micro datasets would not be comparable. The most recent GEM data are available across Visegrád countries for 2013, and this selection is limited by data availability for the Czech Republic that conducted GEM study only three times. Therefore, we only use data for the year 2013 in our analysis, as this is the latest available year for all Visegrád countries (Global Entrepreneurship Monitor, 2013; 2019). We acknowledge that using a relatively old dataset is a limitation of the study; however, since we use it in a novel way - i.e. by differentiating between self-employed with and without employees - we believe that the following analysis has a value for the scholarly community.

In 2013, the GEM data were collected for the Czech Republic by the team from the University of Economics, Prague (see Lukeš et al., 2014 for details); for Hungary by the team of the University of Pécs (see Márkus and Szerb, 2013 for details); for Poland by the team of the University of Economics in Katowice (see Tarnawa et al., 2014 for details); and for Slovakia by the team of the Comenius University in Bratislava (see Pilková et al., 2014 for details). Country teams have to collect within the APS individual data for at least 2000 adults; however, there is no requirement concerning the maximum number of collected responses (Global Entrepreneurship Monitor, 2019). The largest sample in 2013 is for the Czech Republic ( $\mathrm{N}=5$ 009), and the sample size across Visegrád countries is reported in Table 1.

Table 1. Adult Population Survey in V4 countries in 2013: sample size (N)

\begin{tabular}{|l|c|c|}
\hline \multicolumn{1}{|c|}{ Country } & Sample size (N) & Country report GEM \\
\hline Czech Republic & 5009 & Lukeš et al. (2014) \\
\hline Hungary & 2000 & Márkus \& Szerb (2013) \\
\hline Poland & 2000 & Tarnawa et al. (2014) \\
\hline Slovakia & 2007 & Pilková et al. (2014) \\
\hline
\end{tabular}

Source: STATA 14, own calculations based on Global Entrepreneurship Monitor (2013) data.

The APS tracks working status of all kinds of individuals, including part-time workers, retirees, students, unemployed, and other non-economically active individuals. The objective of our study is to better understand individual determinants of self-employment in Visegrád countries and, thus, we restrict our sample only to people economically active, i.e. in 
self-employment or paid employment as typical in the previously published studies (e.g. Kolvereid, 1996; Blanchflower, 2000; Millán et al., 2012; Hytti et al., 2013; Caliendo et al., 2014). Furthermore, we also keep in our sample only established entrepreneurs, who continuously receive income from their business activity, and thus we exclude from the sample all infant business owners (0-3 months) and early-stage (nascent) entrepreneurs (up to 3.5-years-old). The remaining self-employed individuals in the sample managed to survive the first critical years in their business, and they receive regular payments from their economic activity. Global Entrepreneurship Monitor (2013) defines them as owners-managers of established businesses, which means such that operate longer than 3.5 years.

Furthermore, we explore individual determinants of entrepreneurship and self-employment identified in the literature (e.g. Parker, 2004; Simoes et al., 2016; van der Zwan et al., 2016; Boudreaux et al., 2019) and check whether they are available in the GEM 2013 dataset. Unfortunately, the GEM focuses mainly on entrepreneurs themselves rather than on collecting a wide range of variables for individuals with different working status; therefore, we are limited by the potentially available variables. The available variables include gender, age, education, entrepreneurial confidence, and the number of people living in a household, which we later use in our empirical analysis. We describe selected variables in Table 2 and provide readership with summary statistics in Table 3. Presented statistics were weighted over the size 18-64 workforce in each of the countries.

Table 2. List of Variables

\begin{tabular}{|l|l|}
\hline \multicolumn{1}{|c|}{ Variable } & \multicolumn{1}{c|}{ Definition } \\
\hline Employment status & $\begin{array}{l}\text { Employment status as one of three categories: Self-employed with } \\
\text { employees (having at least one employee excluding the owner of } \\
\text { the business), self-employed without employees or in paid em- } \\
\text { ployment. Self-employed are considered to be owners-managers } \\
\text { of an established business for more than 3.5 years. }\end{array}$ \\
\hline Age & Respondent's age. \\
\hline Education & $\begin{array}{l}\text { Set of dummy variables according to the United Nation's educa- } \\
\text { tional classification. }\end{array}$ \\
\hline Entrepreneurial Confidence & $\begin{array}{l}\text { Dummy variable which equals 1 if the respondent answered 'yes' } \\
\text { to the following question 'Do you have the knowledge, skill, and } \\
\text { experience required to start a new business?' }\end{array}$ \\
\hline Number of People in Household & $\begin{array}{l}\text { The number of people living permanently in the respondent's } \\
\text { household. }\end{array}$ \\
\hline Country & Respondent's country of residence. \\
\hline
\end{tabular}

Source: own elaboration based on Global Entrepreneurship Monitor (2013) data.

Table 3. Sample Descriptive Statistics

\begin{tabular}{|l|c|c|}
\hline \multicolumn{1}{|c|}{ Variable } & Frequency (\%) & N \\
\hline Self-employed without Employees (=1) & 3.8 & 7244 \\
Self-employed with Employees (=1) & 9.4 & 7244 \\
Pre-primary education or no education (=1) & 0.0 & 7218 \\
Primary education or first stage of basic education (=1) & 2.0 & 7218 \\
Lower secondary or second stage of basic education (=1) & 6.4 & 7218 \\
(Upper) secondary education (=1) & 63.2 & 7218 \\
Post-secondary non-tertiary education (=1) & 4.7 & 7218 \\
\hline
\end{tabular}




\begin{tabular}{|l|c|c|c|c|c|}
\hline \multicolumn{1}{|c|}{ Variable } & Frequency (\%) & \multicolumn{4}{c|}{ N } \\
\hline First or second stage of tertiary education (=1) & 23.7 & \multicolumn{4}{c|}{7218} \\
Entrepreneurial Confidence (=1) & 50.4 & \multicolumn{4}{|c|}{7023} \\
\hline \multicolumn{1}{|c|}{ Variable } & Mean & SD & Min & Max & N \\
\hline Age & 41.1 & 11.1 & 18 & 64 & 7177 \\
Number of People in Household & 3.3 & 1.4 & 1 & 15 & 7187 \\
\hline
\end{tabular}

Note: Self-employed and wage-employed individuals only. Post-stratification weights applied.

Source: STATA 14, own calculations based on Global Entrepreneurship Monitor (2013) data.

\section{RESULTS AND DISCUSSION}

We follow the methodological approach used in previously published studies on the individual determinants of entrepreneurship (e.g. Djankov et al., 2006; Lukeš et al., 2013; Holienka et al., 2016; Dvouletý, 2018), and we employ multivariate logistic regression analysis to understand the differences between wage-employed, solo, and employer entrepreneurs. Our dependent variables have binary character -i.e. being self-employed with/without employees $=1$, otherwise $=0-$ and the presented logistic regression models are estimated on a sample of self-employed and employed individuals. The sample was extracted from the GEM 2013 dataset. All estimates are weighted over 18-64 workforce per census data in each of the countries. The estimated regression models were found to be statistically significant, and they fulfil the standard econometric assumptions (Wooldridge, 2002; Hoetker, 2007).

Two series of econometric models are presented. The first set of regression models aims to capture differences between solo self-employed and wage-employed individuals (Table 4), while the second set (Table 5) shows the differences between employer entrepreneurs (self-employed with employees) and wage-employed. The empirical strategy aims to address the potential of pooled sample bias (Cowling, 2000) by first estimating separate models for the Czech Republic, Hungary, Poland, and Slovakia and, next, by estimating a pooled model for the whole sample of Visegrád countries. The pooled model includes country dummies to address cross-country heterogeneity. Given this empirical approach, we can see how the individual drivers of entrepreneurship differ across Visegrád countries.

\section{Determinants of Solo Entrepreneurship}

The first empirical insight we may see from the models - aiming to capture the differences between wage-employed and solo self-employed individuals (Table 4) - is that entrepreneurial confidence is the only strongly significant determinant that is stable across all estimated models. The remaining variables are less conclusive. Women seem to be self-employed less often when compared with men in the Czech Republic, Hungary, and Slovakia, as suggested by the negative regression coefficients. However, the statistically significant coefficient was obtained only in the case of Slovakia. When it comes to age, the obtained results suggest mostly positive association, except for Poland; however, the statistically significant coefficient was found only for the Czech Republic. Moreover, we do not find any empirical support for the inverse $u$-shaped relationship between age and the likelihood of being solo self-employed. The role of education is also not straightforward. Education seems to be a strong predictor of solo self-employment in the Czech Republic, where we find a positive and statistically significant association with higher levels of education. Nevertheless, results for the remaining countries are very ambiguous. Finally, once we look from the perspective of 
household size, we may say that in the Czech Republic and Poland there seems to be a negative relationship, which is statistically significant only in the Czech model, while in Slovakia and Hungary, there appears to be a positive association.

Table 4. Individual determinants of solo entrepreneurship in V4 countries in 2013: solo self-employed vs wage-employed

\begin{tabular}{|c|c|c|c|c|c|}
\hline Model number & Model (1) & Model (2) & Model (3) & Model (4) & Model (5) \\
\hline Country-sample & $\begin{array}{c}\text { Czech } \\
\text { Republic }\end{array}$ & Hungary & Poland & Slovakia & $\begin{array}{l}\text { Visegrád } \\
\text { countries }\end{array}$ \\
\hline $\begin{array}{l}\text { Independent variables/ } \\
\text { Dependent variable }(=1)\end{array}$ & \multicolumn{5}{|c|}{ Self-employed without employees } \\
\hline \multirow{2}{*}{ Female } & -0.196 & -0.524 & 0.248 & $-0.637+$ & -0.204 \\
\hline & $(0.204)$ & $(0.341)$ & $(0.372)$ & $(0.373)$ & $(0.150)$ \\
\hline \multirow{2}{*}{ Age } & $0.120+$ & 0.0677 & -0.0850 & 0.0133 & 0.0445 \\
\hline & $(0.0671)$ & $(0.126)$ & $(0.168)$ & $(0.124)$ & $(0.0555)$ \\
\hline \multirow{2}{*}{ Age squared } & -0.00115 & -0.0000387 & 0.00109 & 0.000115 & -0.000201 \\
\hline & $(0.000797)$ & $(0.00146)$ & $(0.00192)$ & $(0.00141)$ & $(0.000642)$ \\
\hline \multirow{2}{*}{$\begin{array}{l}\text { Primary education or first stage of basic } \\
\text { education (reference category) }\end{array}$} & . & \begin{tabular}{|c|}
. \\
\end{tabular} & 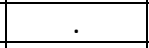 &. & (2) \\
\hline & $()$. & (.) & (.) & (.) & (.) \\
\hline \multirow{2}{*}{$\begin{array}{l}\text { Lower secondary or second stage of } \\
\text { basic education }\end{array}$} & $9.031 * * *$ & -1.355 & & . & -1.065 \\
\hline & $(1.143)$ & $(0.837)$ & &. & $(0.715)$ \\
\hline \multirow{2}{*}{ (Upper) secondary education } & $8.313^{* * *}$ & 0.475 & -1.392 & 0.338 & -0.488 \\
\hline & $(1.052)$ & $(0.738)$ & $(0.944)$ & $(0.393)$ & $(0.678)$ \\
\hline \multirow{2}{*}{ Post-secondary non-tertiary education } & $7.182 * * *$ & -1.156 & -0.616 & . & -0.927 \\
\hline & $(1.460)$ & $(0.967)$ & $(1.042)$ & . & $(0.751)$ \\
\hline \multirow{2}{*}{$\begin{array}{l}\text { First or second stage of tertiary } \\
\text { education }\end{array}$} & $8.448 * * *$ & 0.460 & -1.151 & . & -0.375 \\
\hline & $(1.058)$ & $(0.709)$ & $(0.966)$ & . & $(0.675)$ \\
\hline \multirow{2}{*}{ Entrepreneurial Confidence } & $1.171 * * *$ & $1.902 * * *$ & $2.402 * * *$ & $1.854 * * *$ & $1.476 * * *$ \\
\hline & $(0.226)$ & $(0.363)$ & $(0.568)$ & $(0.491)$ & $(0.172)$ \\
\hline \multirow{2}{*}{ Household Size } & $-0.265 * * *$ & 0.00517 & -0.0786 & 0.0683 & $-0.119 *$ \\
\hline & $(0.0782)$ & $(0.112)$ & $(0.137)$ & $(0.107)$ & $(0.0556)$ \\
\hline \multirow{2}{*}{ Constant } & $-14.17^{* * *}$ & $-6.868 * *$ & -2.202 & $-5.492 *$ & $-4.307 * * *$ \\
\hline & $(1.570)$ & $(2.647)$ & (3.371) & $(2.545)$ & $(1.265)$ \\
\hline Country dummies & No & No & No & No & Yes \\
\hline Observations & 3,164 & 990 & 1,001 & 995 & 6,213 \\
\hline Prob > chi2 & 0.00 & 0.00 & 0.00 & 0.00 & 0.00 \\
\hline Pseudo $R^{2}$ & 0.062 & 0.186 & 0.113 & 0.091 & 0.073 \\
\hline AIC & 1042.6 & 317.1 & 309.2 & 322.1 & 2001.3 \\
\hline $\mathrm{BIC}$ & 1103.2 & 366.1 & 353.4 & 356.4 & 2088.8 \\
\hline
\end{tabular}

Notes: self-employed are owners-managers of established businesses for more than 3.5 years. Countries included in Model 5 (pooled sample of four Visegrád countries): Czech Republic, Hungary, Poland, Slovakia. Poststratification weights applied. Robust standard errors are in parentheses, stat. significance is reported as follows: $+p<0.10, * p<0.05, * * p<0.01, * * * p<0.001$.

Source: STATA 14, own calculations based on Global Entrepreneurship Monitor (2013) data. 


\section{CONCLUSIONS}

The presented article chapter aimed to enrich scholarship on individual determinants of solo and employer entrepreneurship in post-communist economies. The study exploited data from the four Visegrád countries, namely the Czech Republic, Hungary, Poland, and Slovakia, from the 2013 Adult Population survey, a part of the GEM. We utilise the available identified determinants of entrepreneurship and self-employment, including gender, age, education, entrepreneurial confidence, and the number of people living in a household, and we estimate multivariate logistic regression analysis with the aim to understand the differences between wage-employed, solo self-employed, and employer entrepreneurs. Compared to the previously published studies, we estimate separate models for each of the Visegrád countries first and, then, we also estimate a pooled model so as to overcome the problem of pooled sample bias.

The obtained findings from all estimated regression models - regardless of the type of self-employment, i.e. with or without employees - show a strong and positive impact of entrepreneurial confidence on the likelihood of being an established entrepreneur. This agrees with previously published studies on the determinants of entrepreneurship showing the importance of entrepreneurial confidence in the decision to pursue an entrepreneurial career pathway (e.g. Koellinger et al., 2007; Dimov, 2010; Simoes et al., 2016). Nevertheless, observations for remaining variables join the increasing volume of knowledge by showing that self-employed individuals are 'different animals' with and without employees (Burke \& Cowling, 2015; Dvouletý, 2018).

It was quite surprising for us to observe that we were almost unable to see any statistically significant results for the group of solo self-employed individuals. The exception is the Czech Republic, where we noticed that solo self-employment career pathway is positively associated with age and with higher levels of education. A negative relationship was observed for household size and women. Women are also less likely to be self-employed in Slovakia. On the contrary, for the group of job creators, we may see more harmonised patterns, especially in terms of the obtained level of education. Job creation is positively associated with higher levels of education in the Czech Republic and Poland, which corresponds with the recent observations of Dvouletý (2018) indicating that employer entrepreneurs are usually individuals with more senior profiles, both in terms of education and experience. Women are according to the presented findings also less likely to create new jobs, which was again found to be a statistically significant determinant in the Czech Republic and Slovakia. Quite surprisingly, we were unable to observe an inversed u-shaped relationship between age and job creation, previously documented by several scholars (e.g. Cowling et al., 2004; Millán et al., 2014; Dvouletý, 2018). Such a finding might be linked to the context of the post-communist economies. As entrepreneurship has been emerging after the end of the socialist regime, we propose a hypothesis - which may be further tested in later studies - that most of Visegrád entrepreneurs are relatively younger compared to those doing business in the Western European countries.

Unfortunately, the presented findings are limited by the resources we have. The country-level samples are relatively small, and the findings rely on a dataset from just one year. Having a longitudinal dataset or, at least, data for more years (and cohorts of entrepreneurs) would definitely increase the robustness of the presented findings. A larger sample might 
also help in proving statistical significance for the variables that have already been included in the conducted multivariate analysis. Moreover, we need to acknowledge that it would be more proper to have a more recent comparable dataset, which is not currently available. Our research thus also serves as a call for researchers and scholars from those Visegrád countries that have stopped conducting the GEM study, i.e. the Czech Republic and Hungary.

We also need to acknowledge that there are other important individual determinants of entrepreneurship unavailable in the GEM 2013 dataset, which we nevertheless found important in the previous research. These variables should become the subject of future investigation in the context of Visegrád countries. Among other things, scholars should focus on the role of family and partner-entrepreneur relationships and their impact on overall life satisfaction (Shoubaki \& Stephan, 2018), the importance of family background and parental influence (Lindquist et al., 2015), and the role of physical and mental disability in pursuing entrepreneurial career (Jones et al., 2011).

\section{REFERENCES}

Barcik, A., Dziwiński, P., \& Jakubiec, M. (2017). The Potential of Academic Entrepreneurship in Universities of Visegrad Group Countries. Zeszyty Naukowe Politechniki Częstochowskiej Zarzadzanie, 2017(27), 18-35.

Blanchflower, D.G. (2000). Self-employment in OECD countries. Labour Economics, 7(5), 471-505. https://doi.org/10.1016/S0927-5371(00)00011-7

Block, J., \& Sandner, P. (2009). Necessity and opportunity entrepreneurs and their duration in selfemployment: evidence from German micro data. Journal of Industry, Competition and Trade, 9(2), 117-137. https://doi.org/10.1007/s10842-007-0029-3

Bögenhold, D. (2019). From Hybrid Entrepreneurs to Entrepreneurial Billionaires: Observations on the Socioeconomic Heterogeneity of Self-employment. American Behavioral Scientist, 63(2), 129-146. https://doi.org/10.1177/0002764218794231

Bögenhold, D., Klinglmair, A., Parastuty, Z., \& Kandutsch, F. (2019). Micro-entrepreneurship and changing contours of work: towards precarious work relations? Empirical findings from Austria. In W. Conen, J. Schippers, (Eds.) Self-Employment as Precarious Work. Cheltenham: Edward Elgar Publishing.

Boudreaux, C.J., Nikolaev, B.N., \& Klein, P. (2019). Socio-cognitive traits and entrepreneurship: The moderating role of economic institutions. Journal of Business Venturing, 34(1), 178-196. https://doi.org/10.1016/j.jbusvent.2018.08.003

Burk, A., \& Cowling, M. (2015). The use and value of freelancers: The perspective of managers. International Review of Entrepreneurship, 13(1), 7-20.

Burke, A., Lyalkov, S., Millán, A., Millán, J.M., \& van Stel, A. (2019). How do country R\&D change the allocation of self-employment across different types?. Small Business Economics, 1-27. https://doi.org/10.1007/s11187-019-00196-z

Caliendo, M., Fossen, F., \& Kritikos, A.S. (2014). Personality characteristics and the decisions to become and stay self-employed. Small Business Economics, 42(4), 787-814. https://doi.org/10.1007/s11187-013-9514-8

Cieślik, J., \& van Stel, A. (2014). Comparative analysis of recent trends in private sector development in CEE transition economies. Entrepreneurship Research Journal, 4(2), 205-235. https://doi.org/10.1515/erj-2013-0054 
Cieślik, J., \& Dvouletý, O. (2019). Segmentation of the population of the solo self-employed. International Review of Entrepreneurship, 17(3), 281-304.

Coad, A., Nielsen, K., \& Timmermans, B. (2017). My first employee: an empirical investigation. Small Business Economics, 48(1), 25-45. https://doi.org/10.1007/s11187-016-9748-3

Cowling, M. (2000). Are entrepreneurs different across countries?. Applied Economics Letters, 7(12), 785-789. https://doi.org/10.1080/135048500444804

Cowling, M., Taylor, M., \& Mitchell, P. (2004). Job creators. The Manchester School, 72(5), 601-617. https://doi.org/10.1111/j.1467-9957.2004.00411.x

Douglas, E.J., \& Shepherd, D.A. (2002). Self-employment as a career choice: Attitudes, entrepreneurial intentions, and utility maximization. Entrepreneurship theory and practice, 26(3), 81-90. https://doi.org/10.1177/104225870202600305

Dana, L.P., \& Dana, T. (2003). Management and enterprise development in post-communist economies. International Journal of Management and Enterprise Development, 1(1), 45-54. https://doi.org/10.1504/IJMED.2003.003512

Dana, L.P., \& Ramadani, V. (2015). (Eds.) Family businesses in transition economies. Cham: Springer International Publishing.

Davidsson, P. (2015). Data replication and extension: A commentary. Journal of Business Venturing Insights, 3, 12-15. https://doi.org/10.1016/j.jbvi.2015.02.001

Delmar, F. (2015). When the dust has settled: A final note on replication. Journal of Business Venturing Insights, 4, 20-21. https://doi.org/10.1016/j.jbvi.2015.07.001

Djankov, S., Qian, Y., Roland, G., \& Zhuravskaya, E. (2006). Who are China's entrepreneurs?. American Economic Review, 96(2), 348-352. https://doi.org/10.1257/000282806777212387

Dimov, D. (2010). Nascent entrepreneurs and venture emergence: Opportunity confidence, human capital, and early planning. Journal of Management Studies, 47(6), 1123-1153. https://doi.org/10.1111/j.1467-6486.2009.00874.xC

Dvouletý, O. (2017a). What is the Relationship between Entrepreneurship and Unemployment in Visegrad Countries?. Central European Business Review, 6(2), 42-53. https://doi.org/10.18267/j.cebr.179

Dvouletý, O. (2017b). Can policy makers count with positive impact of entrepreneurship on economic development of the Czech regions?. Journal of Entrepreneurship in Emerging Economies, 9(3), 286-299. https://doi.org/10.1108/JEEE-11-2016-0052

Dvouletý, O. (2018). Determinants of Self-employment With and Without Employees: Empirical Findings from Europe. International Review of Entrepreneurship, 16(3), 405-426.

Dvouletý, O. (2019). Development of Entrepreneurial Activity in the Czech Republic over the Years 2005-2017. Journal of Open Innovation: Technology, Market, and Complexity, 5(3), 38. https://doi.org/10.3390/joitmc5030038

Dvouletý, O., Procházka, D.A., \& Starnawska, M. (2019). Who Earns more: Job Creators, Solo-Entrepreneurs or Employees? Empirical evidence from Visegrad Countries. International Journal of Entrepreneurship and Small Business. https://doi.org/10.1504/IJESB.2019.10020600

Ekelund, J., Johansson, E., Järvelin, M.R., \& Lichtermann, D. (2005). Self-employment and risk aversion - evidence from psychological test data. Labour Economics, 12(5), 649-659.

Fairlie, R.W., \& Miranda, J. (2017). Taking the leap: The determinants of entrepreneurs hiring their first employee. Journal of Economics \& Management Strategy, 26(1), 3-34. https://doi.org/10.1111/jems.12176

Fischer, S., Sahay, R., \& Vegh, C.A. (1996). Stabilization and growth in transition economies: the early experience. Journal of Economic Perspectives, 10(2), 45-66. https://doi.org/10.1257/jep.10.2.45 
Gerber, T.P. (2001). Paths to success: individual and regional determinants of self-employment entry in post-communist Russia. International Journal of Sociology, 31(2), 3-37. https://doi.org/10.1080/15579336.2001.11770227

Global Entrepreneurship Monitor. (2019). GEM Entrepreneurial Behaviour and Attitudes. Retrieved from https://www.gemconsortium.org/data/key-aps on September 23, 2019.

Global Entrepreneurship Monitor (2013). GEM 2013 Global Individual Level Data. Retrieved from https://www.gemconsortium.org/data/sets?id=nes on September 23, 2019.

Głodowska, A., Maciejewski, M., \& Wach, K. (2019). How Entrepreneurial Orientation Stimulates Different Types of Knowledge in the Internationalisation Process of Firms from Poland?. Entrepreneurial Business and Economics Review, 7(1), 61-73. https://doi.org/10.15678/EBER.2019.070104

Grace, K. (2018). The impact of personal income tax rates on the employment decisions of small businesses. Journal of Entrepreneurship and Public Policy, 7(1), 74-104.

Hoetker, G. (2007). The use of logit and probit models in strategic management research: Critical issues. Strategic Management Journal, 28(4), 331-343. https://doi.org/10.1002/smj.582Ci

Holienka, M. (2014). Youth entrepreneurship in Slovakia: a GEM based perspective. Comenius Management Review, 8(2), 41-50.

Holienka, M., Pilková, A., \& Jancovicová, Z. (2016). Youth entrepreneurship in Visegrad Countries. Entrepreneurial Business and Economics Review, 4(4), 105-121. https://doi.org/10.15678/EBER.2016.040407

Holienka, M., Gal, P., \& Kovačičová, Z. (2017). Drivers of student entrepreneurship in Visegrad four countries: Guesss evidence. Central European Business Review, 6(2), 54-64. https://doi.org/10.18267/j.cebr.180

Hytti, U., Kautonen, T., \& Akola, E. (2013). Determinants of job satisfaction for salaried and selfemployed professionals in Finland. The International Journal of Human Resource Management, 24(10), 2034-2053. https://doi.org/10.1080/09585192.2012.723023

Kirby, D.A., \& Watson, A. (2017). (Eds.) Small Firms and Economic Development in Developed and Transition Economies: A Reader. New York: Routledge.

Koellinger, P., Minniti, M., \& Schade, C. (2007). 'I think I can, I think I can': Overconfidence and entrepreneurial behavior. Journal of Economic Psychology, 28(4), 502-527. https://doi.org/10.1016/j.joep.2006.11.002

Kolvereid, L. (1996). Organizational employment versus self-employment: Reasons for career choice intentions. Entrepreneurship Theory and Practice, 20(3), 23-31. https://doi.org/10.1177/104225879602000302

Krasniqi, B.A., \& Desai, S. (2016). Institutional drivers of high-growth firms: country-level evidence from 26 transition economies. Small Business Economics, 47(4), 1075-1094.

Jakubczak, J., \& Rakowska, A. (2014). Cultural values and entrepreneurship: Pilot study. In Human capital without borders: Knowledge and learning for quality of life: Proceedings of the Management, Knowledge and Learning International Conference (pp. 529-536). Retrieved from http://www.toknowpress.net/ISBN/978-961-6914-09-3/papers/ML14-586.pdf on September 23, 2019.

Jones, M.K., \& Latreille, P.L. (2011). Disability and self-employment: Evidence for the UK. Applied Economics, 43(2011), 4161-4178. https://doi.org/10.1080/00036846.2010.489816

Laguía, A., García-Ael, C., Wach, D., \& Moriano, J.A. (2019). 'Think entrepreneur-think male': a task and relationship scale to measure gender stereotypes in entrepreneurship. International Entrepreneurship and Management Journal, 15(3), 749-772. https://doi.org/10.1007/s11365-018-0553-0

Lindquist, M., Sol, J., \& van Praag, M. (2015). why do entrepreneurial parents have entrepreneurial children?. Journal of Labor Economics, 33(2), 269-296. https://doi.org/10.1086/678493. 
Lukeš, M., Jakl, M., \& Zouhar, J. (2014). Global Entrepreneurship Monitor 2013 for the Czech Republic (in Czech) / Podnikatelská aktivita v České republice. Retrieved from https://www.mpo.cz/assets/dokumenty/50478/57277/612398/priloha001.pdf on September 23, 2019.

Lukeš, M., Zouhar, J., Jakl, M., \& Očko, P. (2013). Factors influencing entrepreneurial entry: Earlystage entrepreneurs in the Czech Republic. Politická ekonomie, 61(2), 229-247.

Lukeš, M., \& Zouhar, J. (2013). No experience? No problem-it's all about yourself: Factors influencing nascent entrepreneurship outcomes. Ekonomický časopis, 61(9), 934-950.

Lukeš, M., \& Zouhar, J. (2016). The causes of early-stage entrepreneurial discontinuance. Prague Economic Papers, 2016(1), 19-36. https://doi.org/10.18267/j.pep.534

Mahto, R.V., \& McDowell, W.C. (2018). Entrepreneurial motivation: a non-entrepreneur's journey to become an entrepreneur. International Entrepreneurship and Management Journal, 14(3), 513-526. https://doi.org/10.1007/s11365-018-0513-8

Márkus, G., \& Szerb, L. (2013). Global Entrepreneurship Monitor 2013 for Hungary (in Hungarian) / Globális Vállalkozói Monitor Magyarország jelentések. Retrieved from https://www.gemconsortium.org/report on September 23, 2019.

Millán, J.M., Congregado, E., \& Román, C. (2012). Determinants of self-employment survival in Europe. Small Business Economics, 38(2), 231-258. https://doi.org/10.1007/s11187-010-9260-0

Millán, A., Millán, J.M., Román, C., \& Van Stel, A. (2014). Determinants of the own-account worker's decision to hire employees: A review. International Review of Entrepreneurship, 13(2), 129-142.

Money, R.B., \& Colton, D. (2000). The response of the 'new consumer'to promotion in the transition economies of the former Soviet bloc. Journal of World Business, 35(2), 189-205.

Muñoz-Bullón, F., Sánchez-Bueno, M.J., \& Vos-Saz, A. (2015). Nascent entrepreneurs' personality attributes and the international dimension of new ventures. International Entrepreneurship and Management Journal, 11(3), 473-492. https://doi.org/10.1007/s11365-013-0284-1

Ovaska, T., \& Sobel, R.S. (2005). Entrepreneurship in post-socialist economies. Journal of Private Enterprise, 21(1), 8-28.

Parker, S.C. (2004). The economics of self-employment and entrepreneurship. Cambridge University Press.

Petrescu, M. (2016). Self-employed individuals with and without employees: Individual, social and economic level differences. International Review of Entrepreneurship, 14(3), 289-312.

Pilková, A., Holienka, M., Kovačičová, Z., \& Rehák, J. (2014). Global Entrepreneurship Monitor 2013 for Slovakia (in Slovak) / Podnikanie na Slovensku: aktivita, inkluzivita, prostredie. Retrieved from https://www.gemconsortium.org/report on September 23, 2019.

Pilkova, A., \& Kovacicova, Z. (2015). Specifics of the entrepreneurial activities of slovaks: Evidences based on GEM research. Procedia Economics and Finance, 34, 368-375. https://doi.org/10.1016/S2212-5671(15)01642-1

Pilková, A., Jančovičová, Z., \& Kovačičová, Z. (2016). Inclusive entrepreneurship in Visegrad4 countries. Procedia-Social and Behavioral Sciences, 220, 312-320. https://doi.org/10.1016/j.sbspro.2016.05.504

Polok, D., Michalski, P., Szewczyk, D., Keil, D., Wieczore, S., Kaciakova, P., Incze, Z., Rycerz, J., Nisztuk, T., Dvouletý, O., \& Krzemiński, P. (2016). Future of the Visegrad Group. Retrieved from http://serwer1585910.home.pl/upload/source/Think_Paga/raportV4/Future\%20of\%20the\%20Visegrad\%20Group_2016.pdf on September 23, 2019.

Morawska, E. (1999). The malleable homo sovieticus: transnational entrepreneurs in post-communist East Central Europe. Communist and Post-Communist Studies, 32(4), 359-378. https://doi.org/10.1016/S0967-067X(99)00022-7 
Nowiński, W., Haddoud, M.Y., Lančarič, D., Egerová, D., \& Czeglédi, C. (2019). The impact of entrepreneurship education, entrepreneurial self-efficacy and gender on entrepreneurial intentions of university students in the Visegrad countries. Studies in Higher Education, 44(2), 361-379. https://doi.org/10.1080/03075079.2017.1365359

Rees, H., \& Shah, A. (1986). An empirical analysis of self-employment in the UK. Journal of Applied Econometrics, 1(1), 95-108. https://doi.org/10.1002/jae.3950010107

Sachs, J., \& Woo, W.T. (1994). Structural factors in the economic reforms of China, Eastern Europe, and the former Soviet Union. Economic Policy, 9(18), 101-145. https://doi.org/10.2307/1344459

Sauka, A. \& Chepurenko, A. (2017). (Eds.) Entrepreneurship in Transition Economies: Diversity, Trends, and Perspectives. Cham, Switzerland: Springer. https://doi.org/10.1007/978-3-319-57342-7

Shama, A. (1993). Management under fire: The transformation of managers in the Soviet Union and Eastern Europe. Academy of Management Perspectives, 7(1), 22-35.

Shiller, R.J., Boycko, M., Korobov, V., Winter, S.G., \& Schelling, T. (1992). Hunting for Homo Sovieticus: situational versus attitudinal factors in economic behavior. Brookings Papers on Economic Activity, 1992(1), 127-194.

Shoubaki, A.E., \& Stephan, M. (2018). The Life Partner and the Life Satisfaction of the Entrepreneur. Central European Business Review, 2018(3), 26-41. https://doi.org/10.18267/j.cebr.201

Simoes, N., Crespo, N., \& Moreira, S.B. (2016). Individual determinants of self-employment entry: What do we really know?. Journal of Economic Surveys, 30(4), 783-806. https://doi.org/10.1111/joes.12111

Šebestová, J., \& Sroka, W. (2020). Sustainable development goals and SMEs decisions: Czech Republic vs. Poland. Journal of Eastern European and Central Asian Research (JEECAR), 7(1), 39-50. https://doi.org/10.15549/jeecar.v7i1.418

Švejnar, J. (2002). Transition economies: Performance and challenges. Journal of Economic Perspectives, 16(1), 3-28. https://doi.org/10.1257/0895330027058

Szerb, L., \& Imreh, S. (2007). Entrepreneurship Education and Entrepreneurial Attitudes of Hungarian Students: An International Comparison. In Proceedings of 5th International Conference on Management, Enterprise and Benchmarking, MEB (pp. 71-88). Retrieved from https://kgk.uniobuda.hu/sites/default/files/6_Szerb.pdf on September 23, 2019.

Tarnawa, A., Zadura-Lichota, P., Zbierowski, P., \& Nieć, M. (2014). Global Entrepreneurship Monitor 2013 for Poland. Retrieved from https://www.gemconsortium.org/report on September 23, 2019.

van der Zwan, P., Thurik, R., Verheul, I., \& Hessels, J. (2016). Factors influencing the entrepreneurial engagement of opportunity and necessity entrepreneurs. Eurasian Business Review, 6(3), $273-$ 295. https://doi.org/10.1007/s40821-016-0065-1

Van Praag, C.M., \& Ophem, H.V. (1995). Determinants of willingness and opportunity to start as an entrepreneur. Kyklos, 48(4), 513-540. https://doi.org/10.1111/j.1467-6435.1995.tb01282.x

van Stel, A., \& van der Zwan, P. (2019). Analyzing the changing education distributions of solo selfemployed workers and employer entrepreneurs in Europe. Small Business Economics, 1-17. https://doi.org/10.1007/s11187-019-00243-9

Visegrád Group (2019). About the Visegrád Group. Retrieved from http://www.visegradgroup.eu/about/about-the-visegrad-group on September 23, 2019.

Wach, K., \& Wojciechowski, L. (2016). Entrepreneurial Intentions of Students in Poland in the view of Ajzen'-s Theory of Planned Behaviour. Entrepreneurial Business and Economics Review, 4(1), 83-94. https://doi.org/10.15678/EBER.2016.040106 
Wallace, C., \& Latcheva, R. (2006). Economic transformation outside the law: corruption, trust in public institutions and the informal economy in transition countries of Central and Eastern Europe. Europe-Asia Studies, 58(1), 81-102. https://doi.org/10.1080/09668130500401707

Wooldridge, J.M. (2002). Econometric Analysis of Cross Section and Panel Data. Cambridge, MA: The MIT Press.

Zygmunt, J. (2018). Entrepreneurial activity drivers in the transition economies. Evidence from the Visegrad countries. Equilibrium. Quarterly Journal of Economics and Economic Policy, 13(1), 89103. https://doi.org/10.24136/eq.2018.005 


\section{Authors}

The contribution share of authors is equal and amounted to $50 \%$ each of them.

\section{Ondřej Dvouletý}

Ondřej Dvouletý works at the Department of Entrepreneurship at the University of Economics in Prague. He obtained his PhD degree at the University of Economics in Prague. He is an Associate Editor of the Journal of Entrepreneurship in Emerging Economies and the Central European Business Review. Ondrej is also the editor-in-chief of the annual Innovation Management, Entrepreneurship and Sustainability (IMES) conference. His research interest includes determinants of entrepreneurship and self-employment, the evaluation of public entrepreneurship and SME policies, and entrepreneurial economics.

Correspondence to: Department of Entrepreneurship, Faculty of Business Administration, the University of Economics, Prague, W. Churchill Sq. 4, 13067 Prague 3, Czech Republic, e-mail: ondrej.dvoulety@vse.cz

ORCID (ㄴ) http://orcid.org/0000-0001-9151-2033

\section{Marko Orel}

Marko Orel works at the Department of Entrepreneurship at the University of Economics in Prague. He obtained his PhD degree at the University of Ljubljana. His research interest includes exploration of the changing nature of the global workplace, along with the development of on-site and digital collaborative communities. He also explores project and operational networks of influences, community engagement, and inter-relational participation within collaborative workspaces.

Correspondence to: Department of Entrepreneurship, Faculty of Business Administration, the University of Economics, Prague, W. Churchill Sq. 4, 13067 Prague 3, Czech Republic, e-mail: marko.orel@vse.cz

ORCID (1) http://orcid.org/0000-0002-1931-7310

\section{Acknowledgements and Financial Disclosure}

This work was supported by the Internal Grant Agency of the Faculty of Business Administration, University of Economics, Prague under no. IP300040.

\section{Copyright and License}

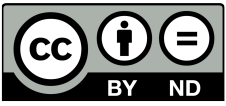

This article is published under the terms of the Creative Commons Attribution - NoDerivs (CC BY-ND 4.0) License http://creativecommons.org/licenses/by-nd/4.0/

Published by Cracow University of Economics - Krakow, Poland

The copyediting and proofreading of articles in English is financed in the framework 
